\title{
Impact of timing of initiation of dialysis on long-term prognosis of patients undergoing hemodialysis
}

\author{
YUMEI ZHANG ${ }^{*}$, CHUN HU*, ZHIXIANG BIAN and PEIHUA CHEN \\ Division of Nephrology, Shanghai Ninth People's Hospital Affiliated to \\ Shanghai Jiaotong University School of Medicine, Shanghai 201900, P.R. China
}

Received December 16, 2016; Accepted June 27, 2017

DOI: $10.3892 /$ etm.2018.6281

\begin{abstract}
There are a lot of controversies pertaining to correctness of timing for the initiation of dialysis in chronic kidney disease (CKD) patients. The present study was conducted to examine the potential association of initiation timing of dialyses with long-term prognosis in CKD patients. In total, 294 patients confirmed as end-stage renal disease (ESRD) were included as study subjects. According to the estimated glomerular filtration rate (eGFR) at initiation time, the patients were classified into four groups based on eGFR: $\geq 10.5,8-10.4,6-8$ and $<6 \mathrm{ml} / \mathrm{min} \times\left(1.73 \mathrm{~m}^{2}\right)^{-1}$. The primary outcomes were defined by all-cause mortality. The median eGFR of the 294 patients at initiation time was $5.43(2.27-13.92) \mathrm{ml} / \mathrm{min} \times\left(1.73 \mathrm{~m}^{2}\right)^{-1}$. The patients with lower eGFR at the start of hemodialysis had a higher proportion of Charlson comorbidity index (CCI) scores of 0-2 and had lower hematocrit. The multivariate Cox regression analysis indicated that CCI, cerebrovascular diseases and chronic obstructive pulmonary disease were significantly associated with all-cause mortality, but not eGFR at the dialysis initiation. Furthermore, stratified analyses confirmed elevated eGFR that had no advantage on long-term prognosis. The present findings have shown that the prevalence of anemia, hyperuricemia and calcium and phosphorus metabolism disorders of patients with low eGFRs at the initiation of hemodialysis was higher in comparison to the patients with high eGFRs. Therefore, the long-term prognosis of patients with high eGFRs prior to hemodialysis was not improved.
\end{abstract}

Correspondence to: Dr Peihua Chen, Division of Nephrology, Shanghai Ninth People's Hospital Affiliated to Shanghai Jiaotong University School of Medicine, 280 Mo He Road, Shanghai 201900, P.R. China

E-mail: chenpeihua201612@163.com

*Contributed equally

Key words: dialysis, initiation time, mortality, hemodialysis prognosis

\section{Introduction}

Chronic kidney disease (CKD) is a general public health concern worldwide. Cases of CKD are on the increase and an estimate suggests that the incidence may be over 3.8 million cases by the end of 2020 (1). Hemodialysis is an important therapy for patients affected with end-stage renal disease (ESRD). Hemodialysis has the ability to relieve patients from complexities associated with the disease and overall ameliorates the patient survival rate. However, there is currently ongoing controversy regarding the correct timing for dialysis initiation $(1,2)$. The US Renal Data System (USRDS) advised to initiate hemodialysis in the patients with glomerular filtration rate (eGFR) of less than $10 \mathrm{ml} / \mathrm{min}^{-1} \mathrm{x}\left(1.73 \mathrm{~m}^{2}\right)^{-1}$. Furthermore, it has been suggested that the timely initiation of hemodialysis often results in improved survival with fewer complications (3). Previous findings showed that a slight delay in the dialysis potentially led to risk to life (4). On the other hand, some reports revealed that early initiation of dialysis could be detrimental to patients and result in harmful clinical outcomes (5-8). Consequently, the present study was planned to explore the association of the initiation of hemodialysis (if any) on the long-term prognosis of CKD patients.

\section{Patients and methods}

Patients. The nature of the present study is prospective observational cohort. The study subjects were patients affected with CKD undergoing treatment at the HD center of Shanghai Ninth People's Hospital (Shanghai, China) between 2005 and 2014. The data were allied to mortality data from the medical records archive of the Ninth People's Hospital through March 31, 2015. The Ethics Committee of the Ninth People's Hospital approved the study and informed consent from all the patients was obtained for the collection of additional venous blood during routine clinical management of the patients. A total of 294 patients $(\geq 18$ years of age) were included in the present study. Exclusion criteria included patients with acute kidney injury or patients with acute-on-chronic renal failure. The study subjects were divided into four groups based on eGFR calculated by the Chronic Kidney Disease Epidemiology Collaboration (CKD-EPI), a simplified formula for filtration rate: $\geq 10.5$, $8-10.4,6-8$ and $\left.<6 \mathrm{ml} / \mathrm{min} \times 1.73 \mathrm{~m}^{2}\right)^{-1}$. 
Table I. Baseline data of patients before hemodialysis.

\begin{tabular}{|c|c|c|c|c|c|c|}
\hline \multirow{2}{*}{$\begin{array}{l}\text { Baseline } \\
\text { conditions }\end{array}$} & \multirow[b]{2}{*}{ All patients } & \multicolumn{4}{|c|}{$\mathrm{eGFR} / \mathrm{ml} / \mathrm{min} \mathrm{x}\left(1.73 \mathrm{~m}^{2}\right)^{-1}$} & \multirow[b]{2}{*}{ P-value } \\
\hline & & $\geq 10.5$ & $8-10.4$ & $6-8$ & $<6$ & \\
\hline No. of patients & 294 & 26 & 29 & 63 & 176 & \\
\hline Age $(\text { years })^{\mathrm{a}}$ & $53.61 \pm 16.32$ & $57.69 \pm 12.22$ & $55.28 \pm 17.93$ & $56.33 \pm 15.63$ & $51.76 \pm 16.66$ & $0.114^{\mathrm{c}}$ \\
\hline Male/female ${ }^{a}$ & $189 / 105$ & $18 / 8$ & $19 / 10$ & $47 / 16$ & $105 / 71$ & 0.182 \\
\hline BMI $\left(\mathrm{kg} / \mathrm{m}^{2}\right)$ & $22.28 \pm 3.48$ & $22.68 \pm 4.79$ & $21.41 \pm 3.96$ & $22.58 \pm 2.78$ & $22.25 \pm 3.40$ & $0.460^{\mathrm{c}}$ \\
\hline $\begin{array}{l}\text { Urine volume } \\
(\mathrm{ml} / \text { day })^{\mathrm{a}}\end{array}$ & $1249.76 \pm 591.04$ & $1367.31 \pm 614.32$ & $1224.14 \pm 570.03$ & $1302.38 \pm 616.60$ & $1217.78 \pm 583.17$ & $0.555^{\mathrm{c}}$ \\
\hline $\begin{array}{l}\text { Mean arterial } \\
\text { pressure }(\mathrm{mmHg})^{\mathrm{a}}\end{array}$ & $127.05 \pm 16.20$ & $128.91 \pm 14.52$ & $126.44 \pm 16.03$ & $123.65 \pm 14.89$ & $128.09 \pm 16.84$ & $0.275^{\mathrm{c}}$ \\
\hline $\begin{array}{l}\text { Renal } \\
\text { insufficiency } \\
\text { (months) }\end{array}$ & $\begin{array}{c}22.00 \\
(0.00-180.00)\end{array}$ & $\begin{array}{c}13.50 \\
(0.00-144.00)\end{array}$ & $\begin{array}{c}24.00 \\
(0.00-180.00)\end{array}$ & $\begin{array}{c}24.00 \\
(0.00-256.80)\end{array}$ & $\begin{array}{c}22.50 \\
(0.00-159.60)\end{array}$ & $0.808^{\mathrm{d}}$ \\
\hline
\end{tabular}

${ }^{\mathrm{a} D a t a}$ expressed as means \pm standard deviation; ${ }^{\mathrm{b}}$ data expressed as medians (ranges); ${ }^{\mathrm{c}}$ one-way ANOVA; ${ }^{\mathrm{d}}$ Wilcoxon test.

Table II. Comorbid diseases of patients.

\begin{tabular}{|c|c|c|c|c|c|c|}
\hline \multirow[b]{2}{*}{ Complications } & \multirow[b]{2}{*}{ All patients, n (\%) } & \multicolumn{4}{|c|}{$\mathrm{eGFR} / \mathrm{ml} / \mathrm{min} \times\left(1.73 \mathrm{~m}^{2}\right)^{-1}$} & \multirow[b]{2}{*}{ P-value } \\
\hline & & $\geq 10.5, \mathrm{n}(\%)$ & $8-10.4, \mathrm{n}(\%)$ & $6-8, \mathrm{n}(\%)$ & $<6, \mathrm{n}(\%)$ & \\
\hline Hypertension & $275(93.5)$ & $24(92.3)$ & $27(93.1)$ & $59(93.7)$ & $165(93.8)$ & $0.993^{\mathrm{a}}$ \\
\hline Diabetes & $71(24.1)$ & $13(50.0)$ & $12(41.4)$ & $16(25.4)$ & $30(17.0)$ & $0.000^{\mathrm{a}, \mathrm{c}}$ \\
\hline $\begin{array}{l}\text { Cerebrovascular } \\
\text { accident }\end{array}$ & $26(8.8)$ & $3(11.5)$ & $4(13.8)$ & $5(7.9)$ & $14(8.0)$ & $0.747^{\mathrm{a}}$ \\
\hline $\begin{array}{l}\text { Cerebral } \\
\text { hemorrhage }\end{array}$ & $2(0.7)$ & $0(0.0)$ & $0(0.0)$ & $0(0.0)$ & $2(1.1)$ & \\
\hline $\begin{array}{l}\text { Cerebral } \\
\text { infarction }\end{array}$ & $24(8.2)$ & $3(11.5)$ & $4(13.8)$ & $5(7.9)$ & $12(6.8)$ & \\
\hline $\begin{array}{l}\text { Ischemic } \\
\text { heart disease }\end{array}$ & $18(6.1)$ & $2(7.7)$ & $2(6.9)$ & $6(9.5)$ & $8(4.5)$ & $0.560^{\mathrm{a}}$ \\
\hline $\begin{array}{l}\text { Congestive } \\
\text { heart failure }\end{array}$ & $55(18.7)$ & $9(34.6)$ & $5(17.2)$ & $7(11.1)$ & $34(19.3)$ & $0.079^{\mathrm{a}}$ \\
\hline $\begin{array}{l}\text { Left ventricular } \\
\text { hypertrophy }\end{array}$ & $139(47.3)$ & $13(50.0)$ & $12(41.4)$ & $28(44.4)$ & $86(48.9)$ & $0.834^{\mathrm{a}}$ \\
\hline Arrhythmia & $75(25.5)$ & $6(23.1)$ & $11(37.9)$ & $20(31.7)$ & $38(21.6)$ & $0.161^{\mathrm{a}}$ \\
\hline $\begin{array}{l}\text { Peripheral } \\
\text { vascular disease }\end{array}$ & $6(2.0)$ & $0(0.0)$ & $1(3.4)$ & $2(3.2)$ & $3(1.7)$ & $0.623^{\mathrm{a}}$ \\
\hline Liver disease & $86(29.3)$ & $9(34.6)$ & $7(24.1)$ & $25(39.7)$ & $45(25.6)$ & $0.158^{\mathrm{a}}$ \\
\hline COPD & $8(2.7)$ & $0(0.0)$ & $1(3.4)$ & $3(4.8)$ & $4(2.3)$ & $0.486^{\mathrm{a}}$ \\
\hline Hyperuricemia & $233(75.9)$ & $13(50.0 \%)$ & $17(58.6)$ & $46(73.0)$ & $147(83.5)$ & $0.000^{\mathrm{a}, \mathrm{c}}$ \\
\hline \multicolumn{7}{|l|}{ CCI score } \\
\hline $0-2$ & $103(35.0)$ & $6(23.1)$ & $7(24.1)$ & $16(25.4)$ & $74(42.0)$ & $0.023^{\mathrm{b}, \mathrm{c}}$ \\
\hline $3-4$ & $135(45.9)$ & $10(38.5)$ & $13(44.8)$ & $33(52.4)$ & $79(44.9)$ & $0.630^{\mathrm{a}}$ \\
\hline$\geq 5$ & $56(19.0)$ & $10(38.5)$ & $9(31.0)$ & $14(22.2)$ & $23(13.1)$ & $0.004^{\mathrm{a}, \mathrm{c}}$ \\
\hline Hyperkalemia & $11(3.7)$ & $1(3.8)$ & $1(3.4)$ & $2(3.2)$ & $7(4.0)$ & \\
\hline Heart failure & $75(25.5)$ & $11(42.3)$ & $7(24.1)$ & $15(23.8)$ & $42(23.9)$ & $0.237^{\mathrm{a}}$ \\
\hline Anorexia & $43(14.6)$ & $4(15.4)$ & $4(13.8)$ & $7(11.1)$ & $28(15.9)$ & $0.819^{\mathrm{a}}$ \\
\hline Metabolic acidosis & $3(1.0)$ & $0(0.0)$ & $0(0.0)$ & $1(1.6)$ & $2(1.1)$ & \\
\hline
\end{tabular}

${ }^{a}$ Kruskal-Wallis; ${ }^{\mathrm{b}} \mathrm{P}<0.05$; ${ }^{\mathrm{c}} \mathrm{P}<0.01$; COPD, chronic obstructive pulmonary disease; CCI, Charlson comorbidity index. 
Table III. Baseline biochemical indexes of patients.

\begin{tabular}{|c|c|c|c|c|c|c|}
\hline \multirow{2}{*}{$\begin{array}{l}\text { Biochemical } \\
\text { index }\end{array}$} & \multirow[b]{2}{*}{ All patients } & \multicolumn{4}{|c|}{$\mathrm{eGFR} / \mathrm{ml} \times \min ^{-1} \times\left(1.73 \mathrm{~m}^{2}\right)^{-1}$} & \multirow[b]{2}{*}{ P-value } \\
\hline & & $\geq 10.5$ & $8-10.4$ & $6-8$ & $<6$ & \\
\hline $\mathrm{BUN}^{\mathrm{a}}(\mathrm{mmol} / \mathrm{l})$ & $33.88 \pm 13.17$ & $20.90 \pm 11.89$ & $27.33 \pm 11.28$ & $30.72 \pm 10.68$ & $38.00 \pm 12.51$ & $0.000^{\mathrm{c}, \mathrm{f}}$ \\
\hline $\operatorname{Scr}^{\mathrm{a}}(\mu \mathrm{mol} / \mathrm{l})$ & $959.14 \pm 440.34$ & $408.35 \pm 85.81$ & $564.45 \pm 7.98$ & $721.35 \pm 112.80$ & $1190.60 \pm 415.89$ & $0.000^{\mathrm{c}, \mathrm{f}}$ \\
\hline $\mathrm{UA}^{\mathrm{b}}(\mu \mathrm{mol} / \mathrm{l})$ & $\begin{array}{c}534.5 \\
(315.0-768.5)\end{array}$ & $\begin{array}{c}399.7 \\
(270-542.7)\end{array}$ & $\begin{array}{c}487.6 \\
(274.9-697.7)\end{array}$ & $\begin{array}{c}535.8 \\
(247.9-805.3)\end{array}$ & $\begin{array}{c}543.5 \\
(379.7-798.9)\end{array}$ & $0.014^{\mathrm{d}, \mathrm{e}}$ \\
\hline $\mathrm{Kt} / \mathrm{V}^{\mathrm{a}}$ & $0.90 \pm 0.50$ & $1.12 \pm 0.56$ & $1.27 \pm 0.63$ & $1.08 \pm 0.50$ & $0.75 \pm 0.40$ & 0.000 \\
\hline $\mathrm{Ca}^{\mathrm{a}}(\mathrm{mmol} / \mathrm{l})$ & $2.03 \pm 0.29$ & $2.00 \pm 0.30$ & $2.14 \pm 0.24$ & $2.09 \pm 0.25$ & $2.00 \pm 0.30$ & $0.029^{c, e}$ \\
\hline $\mathrm{P}^{\mathrm{a}}(\mathrm{mmol} / \mathrm{l})$ & $2.12 \pm 0.69$ & $1.58 \pm 0.43$ & $1.74 \pm 0.56$ & $1.99 \pm 0.56$ & $2.32 \pm 0.71$ & $0.000^{\mathrm{c}, \mathrm{f}}$ \\
\hline $\mathrm{Ca}^{e} \mathrm{P}^{\mathrm{a}}$ & $4.26 \pm 1.36$ & $3.15 \pm 0.96$ & $3.69 \pm 1.15$ & $4.13 \pm 1.15$ & $4.57 \pm 1.39$ & $0.000^{f, c}$ \\
\hline iPTH $^{\mathrm{b}}(\mathrm{ng} / \mathrm{l})$ & $\begin{array}{c}218.00 \\
(20.90-886.49)\end{array}$ & $\begin{array}{c}168.90 \\
(26.80-407.20)\end{array}$ & $\begin{array}{c}125.30 \\
(5.60-440.20)\end{array}$ & $\begin{array}{c}184.85 \\
(8.08-1032.60)\end{array}$ & $\begin{array}{c}284.60 \\
(31.55-991.83)\end{array}$ & $0.000^{\mathrm{d}, \mathrm{f}}$ \\
\hline $\mathrm{Hb}^{\mathrm{a}}(\mathrm{g} / \mathrm{l})$ & $75.97 \pm 19.88$ & $81.62 \pm 18.60$ & $82.93 \pm 20.22$ & $81.41 \pm 21.35$ & $71.99 \pm 18.59$ & $0.001^{\mathrm{c}, \mathrm{f}}$ \\
\hline $\operatorname{Hct}(\%)^{\mathrm{a}}$ & $22.72 \pm 6.13$ & $25.16 \pm 5.33$ & $24.82 \pm 6.45$ & $24.73 \pm 7.11$ & $21.33 \pm 5.41$ & $0.000^{\mathrm{c}, \mathrm{f}}$ \\
\hline $\mathrm{SF}^{\mathrm{b}}(\mu \mathrm{g} / \mathrm{l})$ & $\begin{array}{c}327.59 \\
(26.32-1559.50)\end{array}$ & $\begin{array}{c}229.70 \\
(9.42-2000.00)\end{array}$ & $\begin{array}{c}277.00 \\
(37.68-1655.03)\end{array}$ & $\begin{array}{c}285.40 \\
(9.39-1207.13)\end{array}$ & $\begin{array}{c}363.75 \\
(30.90-1583.73)\end{array}$ & $0.029^{\mathrm{d}, \mathrm{e}}$ \\
\hline $\operatorname{Pro}^{\mathrm{a}}(\mathrm{g} / \mathrm{l})$ & $0.29 \pm 0.08$ & $0.24 \pm 0.07$ & $0.27 \pm 0.08$ & $0.30 \pm 0.08$ & $0.30 \pm 0.08$ & $0.004^{\mathrm{c}, \mathrm{f}}$ \\
\hline $\mathrm{G}(\mathrm{g} / \mathrm{l})^{\mathrm{a}}$ & $27.16 \pm 6.20$ & $27.96 \pm 7.03$ & $28.55 \pm 6.61$ & $27.27 \pm 5.87$ & $26.76 \pm 6.11$ & $0.454^{\mathrm{c}}$ \\
\hline $\mathrm{A}(\mathrm{g} / \mathrm{l})^{\mathrm{a}}$ & $33.68 \pm 6.42$ & $32.58 \pm 7.12$ & $33.90 \pm 7.64$ & $33.06 \pm 6.74$ & $34.03 \pm 5.98$ & $0.592^{c}$ \\
\hline $\mathrm{TC}^{\mathrm{a}}(\mathrm{mmol} / \mathrm{l})$ & $4.24 \pm 1.29$ & $4.65 \pm 1.17$ & $4.24 \pm 1.58$ & $4.33 \pm 1.60$ & $4.15 \pm 1.12$ & $0.308^{c}$ \\
\hline $\mathrm{TG}^{\mathrm{a}}(\mathrm{mmol} / \mathrm{l})$ & $1.55 \pm 0.90$ & $1.59 \pm 1.10$ & $1.35 \pm 0.99$ & $1.62 \pm 0.90$ & $1.56 \pm 0.86$ & $0.603^{c}$ \\
\hline $\mathrm{HDL}^{\mathrm{a}}(\mathrm{mmol} / \mathrm{l})$ & $1.17 \pm 0.41$ & $1.27 \pm 0.41$ & $1.20 \pm 0.40$ & $1.14 \pm 0.36$ & $1.16 \pm 0.43$ & $0.516^{\mathrm{c}}$ \\
\hline $\mathrm{LDL}^{\mathrm{a}}(\mathrm{mmol} / \mathrm{l})$ & $2.36 \pm 1.01$ & $2.66 \pm 0.88$ & $2.33 \pm 1.13$ & $2.46 \pm 1.30$ & $2.29 \pm 0.87$ & $0.315^{\mathrm{c}}$ \\
\hline $\mathrm{Lpa}^{\mathrm{b}}(\mathrm{mmol} / \mathrm{l})$ & $\begin{array}{c}273.55 \\
(36.96-944.52)\end{array}$ & $\begin{array}{c}304.00 \\
(41.80-1900.00)\end{array}$ & $\begin{array}{c}272.00 \\
(21.00-1004.00)\end{array}$ & $\begin{array}{c}281.00 \\
(17.00-1108.15)\end{array}$ & $\begin{array}{c}263.00 \\
(47.14-883.65)\end{array}$ & $0.978^{\mathrm{d}}$ \\
\hline $\mathrm{FPG}^{\mathrm{a}}(\mathrm{mmol} / \mathrm{l})$ & $5.04 \pm 1.42$ & $5.61 \pm 2.90$ & $5.01 \pm 1.29$ & $5.06 \pm 1.21$ & $4.96 \pm 1.21$ & $0.249^{c}$ \\
\hline $\mathrm{SI}^{\mathrm{a}}(\mu \mathrm{mol} / \mathrm{l})$ & $1.70 \pm 9.05$ & $7.94 \pm 4.77$ & $9.44 \pm 6.32$ & $11.61 \pm 6.17$ & $12.49 \pm 10.41$ & $0.127^{c}$ \\
\hline $\mathrm{TRF}^{\mathrm{a}}(\mathrm{g} / \mathrm{l})$ & $1.70 \pm 0.44$ & $1.70 \pm 0.52$ & $1.65 \pm 0.39$ & $1.73 \pm 0.52$ & $1.69 \pm 0.40$ & $0.872^{\mathrm{c}}$ \\
\hline $\mathrm{TS}^{\mathrm{a}}(\%)$ & $27.88 \pm 19.00$ & $20.20 \pm 12.79$ & $24.41 \pm 19.09$ & $29.02 \pm 18.51$ & $28.94 \pm 19.74$ & $0.224^{\mathrm{c}}$ \\
\hline
\end{tabular}

BUN, blood urea nitrogen; Scr, creatinine; UA, blood uric acid; Kt/V, a marker of dialysis adequacy; Ca, calcium; $\mathrm{P}$, phosphorus; $\mathrm{Ca} \mathrm{P}^{\mathrm{e}}$, calcium phosphorus product; iPTH, the whole section of parathyroid hormone; Hb, hemoglobin; Hct, hematocrit; SF, ferritin; Proa , prealbumin; G, globulin; A, albumin; TC, three total cholesterol; TG, triacylglycerol; HDL, high density lipoprotein; LDL, low density lipoprotein; Lpa, apolipoprotein A; FPG, fasting blood glucose; SI, serum iron; TRF, transferrin; TS, transferrin saturation; ${ }^{2}$ data expressed as mean \pm standard deviation; 'data expressed as median (range); ${ }^{\mathrm{c}}$ one-way Anova; ${ }^{\mathrm{d} W i l c o x o n}$; ${ }^{\mathrm{e}} \mathrm{P}<0.05$; ${ }^{\mathrm{f}} \mathrm{P}<0.01$.

Clinical and laboratory information. The clinical indices recorded were the patient age, gender, systolic and diastolic blood pressure, weight, height, $24 \mathrm{~h}$ urinary protein, serum creatinine (mg/dl), eGFR, serum albumin, total cholesterol and triglyceride levels. The body mass index (BMI) of the patients was also recorded.

Evaluation of prognosis. The prognosis was evaluated by estimation of the primary aftermaths of CKD, including cardiovascular events, such as cerebrovascular accidents along with ischemic stroke.

Statistical analysis. Statistical analysis in the present study was performed using the SPSS 16.0 (SPSS, Inc., Chicago, IL, USA). Result data are presented as mean \pm standard deviation. The statistical test one-way ANOVA was utilized for the comparison of mean values. The Wilcoxon test was used for the comparison of skewed data. The Kruskal-Wallis test was employed to analyze categorical variables. Survival was assessed using the Kaplan-Meier analysis, with the significance based on the log-rank test. Relative risk (RR) and 95\% confidence interval (CIs) were calculated for risk factors in a Cox regression analysis by LR forward. Cox regression models were exploited for the comparative analyses of eGFR at initiation time with all-cause mortality. A $\mathrm{P}<0.05$ was considered to indicate a statistically significant difference.

\section{Results}

Baseline characteristics of patients. The median eGFR of all patients at the start of hemodialysis was 5.43 $(2.27-13.92) \mathrm{ml} / \mathrm{min} \mathrm{x}\left(1.73 \mathrm{~m}^{2}\right)^{-1}$. Of the participants, $26(8.8 \%)$ 
Table IV. Causes of death for the four groups of patients.

\begin{tabular}{|c|c|c|c|c|c|}
\hline \multirow[b]{2}{*}{ Causes of death } & \multirow{2}{*}{$\begin{array}{c}\text { All the patients, } \\
\mathrm{n}(\%)\end{array}$} & \multicolumn{4}{|c|}{$\mathrm{eGFR} / \mathrm{ml} / \mathrm{min} \mathrm{x}\left(1.73 \mathrm{~m}^{2}\right)^{-1}$} \\
\hline & & $\geq 10.5, \mathrm{n}(\%)$ & $8-10.4, \mathrm{n}(\%)$ & $6-8, \mathrm{n}(\%)$ & $<6$ \\
\hline No. of patients & $65(22.1)$ & $8(30.8)$ & $11(37.9)$ & $14(22.2)$ & $32(18.2)$ \\
\hline Cardiovascular disease & $12(18.4)$ & $0(0.0)$ & $2(18.2)$ & $2(14.3)$ & $8(25.0)$ \\
\hline Congestive heart failure & $11(16.9)$ & $0(0.0)$ & $1(9.1)$ & $2(14.3)$ & $8(25.0)$ \\
\hline Arrhythmia & $0(0.0)$ & $0(0.0)$ & $0(0.0)$ & $0(0.0)$ & $0(0.0)$ \\
\hline $\begin{array}{l}\text { Acute coronary } \\
\text { syndrome }\end{array}$ & $1(1.5)$ & $0(0.0)$ & $1(9.1)$ & $0(0.0)$ & $0(0.0)$ \\
\hline $\begin{array}{l}\text { Cerebrovascular } \\
\text { accident }\end{array}$ & $14(21.5)$ & $1(12.5)$ & $1(9.1)$ & $5(35.7)$ & $7(21.9)$ \\
\hline $\begin{array}{l}\text { Cerebral } \\
\text { hemorrhage }\end{array}$ & $9(13.8)$ & $0(0.0)$ & $1(9.1)$ & $3(21.4)$ & $5(15.6)$ \\
\hline $\begin{array}{l}\text { Cerebral } \\
\text { infarction }\end{array}$ & $5(7.7 \%)$ & $1(12.5)$ & $0(0.0)$ & $2(14.3)$ & $2(6.3)$ \\
\hline $\begin{array}{l}\text { Multiple } \\
\text { organ failure }\end{array}$ & $10(15.4)$ & $3(37.5)$ & $2(18.2)$ & $2(14.3)$ & $3(9.4)$ \\
\hline Infection & $13(20.0)$ & $2(25.0)$ & $3(27.3)$ & $2(14.2)$ & $6(18.8)$ \\
\hline Pulmonary infection & $10(15.4)$ & $1(12.5)$ & $2(18.2)$ & $1(7.1)$ & $6(18.8)$ \\
\hline Other infection & $3(4.6)$ & $1(12.5)$ & $1(9.1)$ & $1(7.1)$ & $0(0.0)$ \\
\hline Malignant tumor & $6(9.2)$ & $1(12.5)$ & $1(9.1)$ & $1(7.1)$ & $3(9.4)$ \\
\hline Unknown & $4(6.0)$ & $1(12.5)$ & $1(9.1)$ & $0(0.0)$ & $2(6.3)$ \\
\hline
\end{tabular}

Table V. Univariate Cox regression analysis of the prognosis of hemodialysis patients.

\begin{tabular}{lcccr}
\hline Items & $\beta$ & RR & $95 \%$ CI & P-value \\
\hline CCI score & & & & \\
$3-4$ & 0.832 & 2.297 & $1.118-4.717$ & 0.024 \\
$\geq 5$ & 1.881 & 6.559 & $3.163-13.605$ & 0.001 \\
Diabetes & 0.807 & 2.241 & $1.366-3.676$ & 0.001 \\
Cerebrovascular & 1.483 & 4.406 & $2.491-7.793$ & $<0.001$ \\
disease & & & $1.165-5.708$ & 0.019 \\
Ischemic heart & 0.947 & 2.579 & $1.511-4.214$ & $<0.001$ \\
disease & & & $2.765-13.451$ & $<0.001$ \\
Heart failure & 0.926 & 2.523 & $1.008-1.043$ & 0.005 \\
COPD & 1.808 & 6.099 & $0.911-0.983$ & 0.004 \\
Age & 0.025 & 1.025 & $0.999-1.000$ & 0.020 \\
Albumin & -0.055 & 0.946 & $1.097-1.729$ & 0.006 \\
Serum creatinine & -0.001 & 0.999 & 1.377 &
\end{tabular}

CCI, Charlson comorbidity index; RR, relative risk; CI, confidence interval; COPD, chronic obstructive pulmonary disease.

had a creatinine-based eGFR $\geq 10.5 \mathrm{ml} / \mathrm{min} \times\left(1.73 \mathrm{~m}^{2}\right)^{-1}$, $63(21.4 \%)$ had an eGFR of $8-10.4 \mathrm{ml} / \mathrm{min} \times\left(1.73 \mathrm{~m}^{2}\right)^{-1}, 29$ $(9.9 \%)$ had an eGFR of $6-8 \mathrm{ml} / \mathrm{min} \mathrm{x}\left(1.73 \mathrm{~m}^{2}\right)^{-1}$, and 176 $(59.9 \%)$ had an eGFR of $<6 \mathrm{ml} / \mathrm{min} \times\left(1.73 \mathrm{~m}^{2}\right)^{-1}$. As shown in Table I, there were no statistical differences in age, BMI, mean arterial pressure, course of renal insufficiency, serum albumin and residual urine volume among groups. As shown in Table II, the patients with lower eGFR had a lower Charlson comorbidity index (CCI) (score, 0-2) $(\mathrm{P}<0.05)$, a higher percentage of incidence of hyperuricemia $(\mathrm{P}<0.05)$ and increased incidence of diabetes $(\mathrm{P}<0.05)$. There were no statistically significant differences in the levels of blood lipids, globulin, albumin, and fasting glucose. However, indicators such as serum urea, creatinine, uric acid, serum phosphorus, 
Table VI. Multivariate Cox regression analysis of the prognosis of hemodialysis patients.

\begin{tabular}{lcccc}
\hline Items & $\beta$ & RR & $95 \%$ CI & P-value \\
\hline Creatinine & -0.001 & 0.999 & $0.998-0.999$ & 0.0109 \\
CCI scores & & & & 0.192 \\
$3-4$ & 0.527 & 1.693 & $0.768-3.734$ & 0.00557 \\
$\geq 5$ & 1.206 & 3.342 & $1.424-7.842$ & 0.0502 \\
Cerebral vascular disease & 0.690 & 1.995 & $0.999-3.981$ & 0.000946 \\
COPD & 1.661 & 5.266 & $1.967-14.099$ & 0.0196 \\
Triacylglycerol & 0.264 & 1.303 & $1.043-1.626$ & \\
\hline
\end{tabular}

CCI, Charlson comorbidity index; RR, relative risk; CI, confidence interval.

calcium-phosphorus product, and ferritin increased gradually ( $\mathrm{P}<0.05$ for all values) (Table III).

Analysis of causes of death. The median follow-up time was 19 (range, 0-60) months. During this period, 65 patients $(22.1 \%)$ died, 194 patients $(66 \%)$ survived and continued on hemodialysis, 27 patients $(9.2 \%)$ underwent renal transplantation, and 8 patients $(2.7 \%)$ were lost to follow up. The primary cause of death was cerebrovascular accident. Fourteen patients (21.5\%) died from cerebrovascular accident, including 9 patients (13.8\%) from cerebral hemorrhage, and 5 patients $(7.7 \%)$ from cerebral infarction. Infection was the second leading cause of death, with 13 patients (20\%). Among these 13, 10 patients (15.4\%) died from pulmonary infection. Cardiovascular disease was the third leading cause of death, with 12 patients (18.4\%), 11 patients (16.9\%) succumbed to heart failure, and 10 patients (15.4\%) succumbed to multiple organ failure. Another 4 patients $(6 \%)$ died from unknown causes (Table IV).

Analysis of prognosis and survival. The univariate Cox regression analysis showed that the long-term prognosis of hemodialysis patients had no significant relationship with residual renal function at the start of hemodialysis. The protective factors affecting long-term prognosis included serum creatinine and albumin; the risk factors included CCI scores and complications with diabetes, cerebrovascular disease, ischemic heart disease, cardiac insufficiency, chronic obstructive pulmonary disease (COPD), age, and triacylglycerol level (Table V). Factors of statistical significance in the univariate Cox regression analysis were used for the multivariate Cox regression analysis, using a forward stepwise regression method (Forward LR). The results indicated that the long-term prognosis of hemodialysis patients was associated with the following factors: CCI scores, complications with cerebral vascular disease or COPD, triacylglycerol level, and serum creatinine level (Table VI).

\section{Discussion}

The proportion of patients undergoing dialysis when their eGFR were over $10 \mathrm{ml} / \mathrm{min}$ is on the increase according to USRDS data (9). The present study involved 294 hemodialysis patients. The results of the multivariate Cox regression analysis revealed that serum creatinine was a protective factor for the long-term prognosis of patients undergoing hemodialysis. Although serum creatinine was an important predictor of prognosis, it did not completely reflect the level of residual renal function according to the current consensus. Consequently, the eGFR estimation at the time of hemodialysis initiation is an important index and holds strong clinical potential.

The present study did not support the fact that eGFR at initiation of hemodialysis was a protective factor for long-term prognosis. Previous findings have shown that early initiation of hemodialysis cannot prolong the life of patients with ESRD $(5,10-13)$. Most of those studies were retrospective studies with large sample sizes, and the results have a certain clinical value. Following a meta-analysis of 15 large prospective and retrospective studies involving initiation of dialysis time, Pan et al (14) confirmed high rates of mortality in patients undergoing early hemodialysis. On the other hand, an earlier study favored the early initiation of hemodialysis as it was useful to achieve clinical benefits including prevention of fatal uremic complications (15). Furthermore, the existence of survival risks such as low residual renal function, low immunity, and dialysis-associated complication should be taken into consideration.

Firstly, residual renal function affected the survival as well as quality of life of the affected patients. The prognosis of patients whose residual renal function rapidly declined was significantly worse in comparison to the patients with good preservation of residual renal function $(16,17)$. Hemodialysis was shown to rapidly damage residual renal function (18-20). Of the 194 patients who survived and continued hemodialysis in the present study, $75.4 \%$ had decreased urine output to $100 \mathrm{ml}$ per day within 24 months, with the median time of 8 months (1-52 months). The primary reason for the worse prognosis with early dialysis initiation was rapid pace of decline in residual renal function.

Secondly, previous findings revealed the application of dialysis could lead to protein loss in CKD patients (21). Low eGFR values at the time of dialysisinitiation were associated with poor nutritional status in some recent studies (21-23). In addition, hemodialysis patients chronically contact the non-physiological dialysis membrane and dialysis fluid, which persistently stimulates the immune system and causes dysregulation of immune mechanisms (mainly low cellular immunity). This results in high rates of infection and mortality, severely 
affecting quality of life and survival (22). In the present study, infection was the second leading cause for mortality.

The technical aspects of hemodialysis such as vascular accesses and blood purification methods, in addition to interdialytic weight gain, may affect the prognosis of patients via fluctuations of blood pressure and volume load, changes of ventricular structure and calcium phosphorus metabolism. In the present study, cardiovascular disease was the third leading cause of death. The factors affecting the prognosis of patients undergoing hemodialysis are varied and complicated. The present study did not find any significant relationship between timing of initiation of dialysis and long-term prognosis. Furthermore, an earlier study on the eGFR, resulted in overestimation in the patients with low serum creatinine levels (23). Thus, eGFR was not considered as the only factor used to guide dialysis initiation time.

This prospective study was inevitably influenced by the following factors: First, patients with earlier initiation of hemodialysis experienced more comorbidities $(8,24)$ and the general conditions were worse than patients with lower eGFR. The high burden of comorbidities were potentially the root cause of poor survival. The present results have shown that higher eGFR at dialysis initiation was associated with higher proportions of patients with CCI $\geq 5$ and diabetes. Earlier studies, also confirmed the paradoxical association of early initiation of dialysis with poor survival $(25,26)$.

Secondly, some patients with ESRD did not have time to initiate hemodialysis and were not saved in time because of severe complications. In the present study, the patients who died before dialysis were excluded from the analyses. Such patients were likely to have lower eGFR. Furthermore, the initiation times of hemodialysis of patients in this study were much later than the international dialysis standards $(27,28)$.

Thirdly, survival time was calculated from the date hemodialysis commenced rather than the date of diagnosis with the same residual renal function. Consequently, the late initiation of dialysis underestimated the survival time.

In summary, early initiation of dialysis did not provide a survival advantage for patients undergoing hemodialysis. This may be associated with the protection of residual renal function, low immunity, and complex hemodialysis techniques, suggesting deferring of hemodialysis. However, with time of initiation of dialysis postponed, complications and severity of disease increased, suggesting that late initiation of dialysis increased the risk of death. This single-center study with limited data collection makes the results of this study difficult to generalize to all populations. Therefore, future investigations remain to be conducted to confirm the results obtained in the present study.

\section{Acknowledgements}

Not applicable.

\section{Funding}

The present study was supported by the Science Fund Project of Shanghai Jiaotong University School of Medicine (no. 13XJ10056) and the Science Research Tasks of Shanghai Municipal Commission of Health and Family Planning (201440331).

\section{Availability of data and materials}

All data generated or analyzed during this study are included in this published article.

\section{Authors' contributions}

$\mathrm{YZ}$ and $\mathrm{CH}$ analysed the data and wrote the manuscript. $\mathrm{ZB}$ contributed to the conception of the study and PC collected the clinical and laboratory information. All authors read and approved the final manuscript.

\section{Ethics approval and consent to participate}

The study was approved by the Ethics Committee of Shanghai Ninth People's Hospital (Shanghai, China) and informed consents were signed by the patients and/or guardians.

\section{Patient consent for publication}

Not applicable.

\section{Competing interests}

The authors declare that they have no competing interests.

\section{References}

1. Zhang QL and Rothenbacher D: Prevalence of chronic kidney disease in population-based studies: Systematic review. BMC Public Health 8: 117, 2008.

2. Faust J and Schreiner O: Early versus late initiation of dialysis. N Engl J Med 363: 2368-2369, 2010.

3. U.S. Renal Data System: USRDS 2009 annual data report: Atlas of chronic kidney disease and end-stage renal disease in the United States. National Institutes of Health, National Institute of Diabetes and Digestive and Kidney Diseases, Bethesda, MD, 2009.

4. Rosansky S, Glassock RJ and Clark WF: Early start of dialysis: A critical review. Clin J Am Soc Nephrol 6: 1222-1228, 2011.

5. Stel VS, Dekker FW, Ansell D, Augustijn H, Casino FG, Collart F, Finne P, Ioannidis GA, Salomone M, Traynor JP, et al: Residual renal function at the start of dialysis and clinical outcomes. Nephrol Dial Transplant 24: 3175-3182, 2009.

6. Liberek T, Warzocha A, Galgowska J, Taszner K, Clark WF and Rutkowski B: When to initiate dialysis-is early start always better? Nephrol Dial Transplant 26: 2087-2091, 2011.

7. Crews DC, Scialla JJ, Liu J, Guo H, Bandeen-Roche K, Ephraim PL, Jaar BG, Sozio SM, Miskulin DC, Tangri N, et al: Developing evidence to inform decisions about effectiveness (DEcIDE) patient outcomes in end stage renal dsease study investigators: Predialysis health, dialysis timing, and outcomes among older United States adults. J Am Soc Nephrol 25: 370-379, 2014.

8. Susantitaphong P, Altamimi S, Ashkar M, Balk EM, Stel VS, Wright S and Jaber BL: GFR at initiation of dialysis and mortality in CKD: A meta-analysis. Am J Kidney Dis 59: 829-840, 2012.

9. Rosansky SJ and Clark WF: Has the yearly increase in the renal replacement therapy population ended? J Am Soc Nephrol 24: 1367-1370, 2013.

10. Sawhney S, Djurdjev O, Simpson K, Macleod A and Levin A: Survival and dialysis initiation: Comparing British Columbia and Scotland registries. Nephrol Dial Transplant 24: 3186-3192, 2009.

11. Cooper BA, Branley P, Bulfone L, Collins JF, Craig JC, Fraenkel MB, Harris A, Johnson DW, Kesselhut J, Li JJ, et al: Ideal study: A randomized, controlled trial of early versus late initiation of dialysis. N Engl J Med 363: 609-619, 2010.

12. Clark WF, Na Y, Rosansky SJ, Sontrop JM, Macnab JJ, Glassock RJ, Eggers PW, Jackson K and Moist L: Association between estimated glomerular filtration rate at initiation of dialysis and mortality. CMAJ 183: 47-53, 2011. 
13. Evans M, Tettamanti G, Nyrén O, Bellocco R, Fored CM and Elinder CG: No survival benefit from early-start dialysis in a population-based, inception cohort study of Swedish patients with chronic kidney disease. J Intern Med 269: 289-298, 2011.

14. Pan Y, Xu XD, Guo LL, Cai LL and Jin HM: Association of early versus late initiation of dialysis with mortality: Systematic review and meta-analysis. Nephron Clin Pract 120: 121-131, 2012.

15. Liu H, Peng Y, Liu F, Xiao H, Chen X, Huang A and Liu Y: Renal function and serum albumin at the start of dialysis in 514 Chinese ESRD in-patients. Ren Fail 30: 685-690, 2008.

16. Liebman SE, Bushinsky DA, Dolan JG and Veazie P: Differences between dialysis modality selection and initiation. Am J Kidney Dis 59: 550-557, 2012.

17. Kim SG and Kim NH: The effect of residual renal function at the initiation of dialysis on patient survival. Korean J Intern Med 24: 55-62, 2009

18. Zhang M, Wang M, Li H, Yu P, Yuan L, Hao C, Chen J and Kalantar-Zadeh K: Association of initial twice-weekly hemodialysis treatment with preservation of residual kidney function in ESRD patients. Am J Nephrol 40: 140-150, 2014

19. Lemes HP, Araujo S, Nascimento D Cunha D, Garcia C, Queiroz V and Ferreira-Filho SR: Use of small doses of furosemide in chronic kidney disease patients with residual renal function undergoing hemodialysis. Clin Exp Nephrol 15: 554-559, 2011.

20. Orasan RA, Patiu IM, Anghel D, Bejan C, Iosub L, Totolici C, Pop M, Turcea C, Teodoru C, Orasan $\mathrm{OH}$, et al: Variation of clinical and laboratory features in chronic dialysis patients treated with high-flux hemodialysis after switching to online hemodiafiltration. Int Urol Nephrol 45: 1415-1422, 2013.

21. Mehrotra R, Duong U, Jiwakanon S, Kovesdy CP, Moran J, Kopple JD and Kalantar-Zadeh K: Serum albumin as a predictor of mortality in peritoneal dialysis: Comparisons with hemodialysis. Am J Kidney Dis 58: 418-428, 2011.

22. Nguyen DB, Lessa FC, Belflower R, Mu Y, Wise M, Nadle J, Bamberg WM, Petit S, Ray SM, Harrison LH, et al: Active bacterial core surveillance (ABCs) MRSA investigators of the emerging infections program: Invasive methicillin-resistant Staphylococcus aureus infections among patients on chronic dialysis in the United States, 2005-2011. Clin Infect Dis 57: $1393-1400,2013$.
23. Grootendorst DC, Michels WM, Richardson JD, Jager KJ, Boeschoten EW, Dekker FW and Krediet RT; NECOSAD study group: The MDRD formula does not reflect GFR in ESRD patients. Nephrol Dial Transplant 26: 1932-1937, 2011.

24. Oh KH, Hwang YH, Cho JH, Kim M, Ju KD, Joo KW, Kim DK, Kim YS, Ahn C and Oh YK: Outcome of early initiation of peritoneal dialysis in patients with end-stage renal failure. J Korean Med Sci 27: 170-176, 2012

25. Lassalle M, Labeeuw M, Frimat L, Villar E, Joyeux V, Couchoud C and Stengel B: Age and comorbidity may explain the paradoxical association of an early dialysis start with poor survival. Kidney Int 77: 700-707, 2010.

26. Kazmi WH, Gilbertson DT, Obrador GT, Guo H, Pereira BJ, Collins AJ and Kausz AT: Effect of comorbidity on the increased mortality associated with early initiation of dialysis. Am J Kidney Dis 46: 887-896, 2005.

27. Beddhu S, Samore MH, Roberts MS, Stoddard GJ, Ramkumar N, Pappas LM and Cheung AK: Impact of timing of initiation of dialysis on mortality. J Am Soc Nephrol 14: 2305-2312, 2003.

28. Crews DC, Scialla JJ, Boulware LE, Navaneethan SD, Nally JV Jr, Liu X, Arrigain S, Schold JD, Ephraim PL, Jolly SE, et al; DEcIDE Network Patient Outcomes in End Stage Renal Disease Study Investigators: Comparative effectiveness of early versus conventional timing of dialysis initiation in advanced CKD. Am J Kidney Dis 63:806-815, 2014. International (CC BY-NC-ND 4.0) License. 